Can, N./ Sosyal Bilimler Araştırmaları Dergisi. 2, (2006): 137-161

\title{
Öğretmen Liderliği Ve Engelleri
}

\author{
Niyazi Can ${ }^{\mathrm{a}}$
}

Özet

Araştırma, ilköğretim ve orta öğretim okullarındaki öğretmenlerin öğretmen liderliği davranışlarını göstermelerinin engellerini saptamak amacıyla yapılmıştır. Araştırma problemiyle ilgili veriler alanyazın taraması ve mülakat yolu ile toplanmıştır..Öğretmen ve yöneticilere göre, öğretmen liderlerin gösterdikleri davranışlar incelendiğinde önemli benzerlikler ortaya çıkmıştır. Ancak öğretmenler sınıfla ilgili öğretim etkinliklerini, yöneticiler ise disiplini ve okul çaplı etkinlikleri daha çok belirtmişlerdir. Öğretmen liderliğinde müdürün öğretmenleri güdülemesi, destek ortamı sunması çok önemsenmiştir. Müdürün ortam ve olanakları yeterince sunmaması durumunda etkinliklerin sınıf içi sınırlarda kalacağı belirtilmiştir. Öğretmen liderliği davranışlarının gösterilmesinde yöneticilerin etkisini okul müdürleri de paylaşmakta ancak öncelikli çabanın öğretmenin göstermesi gerektiği, yöneticinin gösterilen çabaları destekleyeceği paylaşılmıştır. Öğretmen liderliği davranışlarının engelleri yöneticilere ve öğretmenlere göre ayrıca okul türlerine göre benzerlik göstermektedir. İlk sıralarda paylaşılan engeller: Okul kültürüyle ilgili engeller, mesleksel yetişme sürecindeki yetersizlik, yönetim desteğinin yetersizliği, zaman sinırlılığı, öğretmenin formal yükü, diğer öğretmenlerin yetersiz desteği, yetişme ve gelişme ortamının yetersizliği, ilave çabaların değerlendirilmemesi, demokratik güven ve katılım ortamının yetersizliği. Bunlardan yönetim desteği ve demokratik katılımın yetersizliği ile yapılan etkinlik ve kazanımların yeterince değerlendirilmemesi engellerine öğretmenler daha fazla katılmışlardır.
\end{abstract}

Anahtar Sözcükler: Öğretmen liderliği, liderlik davranışları, öğretmen liderliği engelleri.

\begin{abstract}
The research has been done so as to determine the obstacles preventing teachers working at primary and secondary schools from demonstrating teacher leadership attitudes. The data regarding the problem of the research has been gathered by means of literature search and interview. According to the teachers and the principals, it has been noticed that there is a considerable amount of similarity in teachers'demonstrating leadership attitudes. However, teachers focused on class-involved activities whereas
\end{abstract}

${ }^{a}$ Doç. Dr. Erciyes Üniversitesi, Eğitim Fakültesi, Kayseri, niyazic@erciyes.edu.tr 
Can, N./ Sosyal Bilimler Araştırmaları Dergisi. 2, (2006): 137-161

principals focused on school-sized activities and discipline. In the context of teacher leadership,principal's motivating teachers and providing an atmosphere of support are of primary importance. It has been stated that principals' failure in providing the required atmosphere and facilites will lead to the fact that educational activities will have to be held within the borders of the classroom. The effectiveness of principals on teachers' demonstrating leadership attitudes has been admitted by principals as well. However principals have been found to believe that teachers must be the first to pay effort in acquiring and demonstrating leadership attitudes and that principals will support them. Obstacles regarding leader teachership reveal similarities in respect of such components as principals, teachers and types of schools. Of these similarities are the most noticeable ones are: obstacles regarding school-culture, insufficiency in the process of professional development,lack in administrational support, shortage of time, teachers' formal duties, lack of colleberation between teachers, insufficiency in the ambience of training and development and democratical reliance and participation, neglecting teachers'extra efforts. Among the above-mentioned obstacles, lack of principals' support, democratical participation and insufficiency in evaluating the acquisitons are the ones teachers agree with much more strongly.

Keywords: Teacher Leadership, leadership attitiudes, teacher leadership obstacles

\section{Giriş}

Yönetim alanında araştırma yapan bilim adamlarının yoğun olarak üzerinde çalıştıkları konulardan biri liderliktir. Liderlik konusunda çok değişik tanımlar yapılmıştır. Liderlikle ilgili; grup hedeflerine ulaşma doğrultusunda grubun etkinliklerini etkileme süreci, izleyici ile lider konumundaki kişi arasında oluşan bir etkileşim, küme üzerinde olumlu etkide bulunabilme gücü gibi tanımlar yapılabilir. Liderlikle ilgili olarak yapılan tanımlamalar, liderliğin farklı yönlerini ele almıştır (Çelik, 1999). Aynı zamanda yapılan eyleme ve yapanın konumuna göre de farklı liderlik rolleri ve teorileri ortaya çıkmıştır. Eğitimsel liderlik, öğretim liderliği, yönetim liderliği, öğretmen liderliği gibi.

Geleneksel olarak bireysel rol veya sorumlulukla eşdeğer tutulan liderlik teorisinin anlamı son zamanlarda genişletilmektedir. Mevcut olan liderlik teorisi, liderliğin bireyselliği korumadığını desteklemekle birlikte, amaçlı etkilerle sosyal etkilenimin bir kişinin (veya grup) ötesinde diğer kişiler veya grupların aktivitelerini ya da ilişkilerini yapılandırdığını desteklemektedir 
(Yukl, 1994). Liderler, insanların kişisel ve ortak potansiyelini gün yüzüne çıkaran, seçeneklerini çoğaltan, hedefe ulaşmaları konusunda motive eden kişilerdir. Bu rolün pek çok yöntemi bulunmakla birlikte hepsi ortak bir amaca hizmet eder ve bu ortak amaç okullarda daha çok sayıda öğrencinin daha iyi öğrenmesi şansını artırmak şeklinde ortaya çıkar (Urbanski ve Nickolaou, 2006).

\section{Kavramlar}

Okulları yeniden yapılandırma hareketi devam ettikçe, öğretmenlerden okullarda liderlik rollerini oynamaları istenmektedir. Geçmişte liderlik rolleri, alanlarıyla sınırlıydı ve okul yöneticilerinin yetkisindeydi. Öğretmenler uzun süre takım lideri, bölüm başkanı, kurum lideri ve program geliştiricisi olarak hizmet ettiler. Artık öğretmenlik mesleğine destek olarak gelişen liderlik rolleri, öğretmenlerin her gün öğrencilerle iletişim içinde, müfredat ve öğretim hakkında kritik kararlar vermek için en iyi pozisyonda oldukları kanısına dayanıyor. Bunlar öğretmen rollerinin genişlemekte olduğu düşüncesini desteklemektedir. Öğretmen rollerini farklı anlama ve genişletme hareketi, kaliteli öğretmenleri etkileme ve elde tutma gereksiniminden kaynaklanıyor (Dimock ve Mc Gree, 1995; Livingston, 1992; Carnegie Forum, 1986).

Öğretmen liderliğinin tanımı hakkında vurgulanan bir çok önemli husus vardır: İlk olarak öğretmen liderliğinin; okul etkinliği ve okul gelişimine katkıda bulunabildiğini gösteren kanıtı, öğretmenler arasında öğrenci normlarının oluşumu ile ilgilidir. İkinci olarak, öğretmen liderliğinin, okul içerisinde ilişkilerin ve eğitimin kalitesi üzerine pozitif bir etkiye sahip olduğunu gösteren araştırmaların, öğretmenlere liderlik için firsatlar vermesi ile eşit sayılmasıdır. En pratik seviyesi olan üçüncüsünde ise öğretmen liderliği; müfredat1, öğretmeyi ve öğrenmeyi etkileyen öğretmenlerin eğitimsel liderler olarak çalışması anlamına gelmektedir. Son olarak, öğretmen liderliği, liderliğin sadece bireysel eylemlerden çok kişiler arası ilişkilerin dinamiğinin ç1ktısı olduğunu vurgulayan yeniden-külttürlenen okullar ile ilgilidir Burada öğretmen liderliğinin sınıf dışına taşan işlevlerine vurgu yapılmaktadır (Harris, 2005:206). Çünkü, sınıf duvarları bir kafes gibi düşünülmemelidir (Urbanski ve 
Can, N./ Sosyal Bilimler Araştırmaları Dergisi. 2, (2006): 137-161

Nickolaou, 2006). Debbie Meier ve meslektaşları bunun gerçekleştirilebileceğini ancak bunun pek de kolay olmayacağını işaret etmektedir. Bunun liderliği yaygınlaştırmakla ilgili olduğu söylenebilir. Liderliği yaygınlaştırmak, öğrenci-merkezli kültürü yerleştirmek ve okullanı "öğrenim” kurumları haline getirmek mümkündür. Bazı yazarlar da liderliğin bedelinin öğrenime odaklanmak ve kültür oluşturmak olduğunu ifade etmişlerdir (Urbanski ve Nickolaou, 2006).

Bir okul içerisinde öğretmen liderliğinin başarısı veya başarısızlığı, diğer öğretmen tutumları, okul yönetimi ile ilişkiler gibi kişiler arası birçok faktörden etkilenebilmektedir (Katzenmeyer ve Moller, 2001). Hem öğretmenin meslektaşlarını etkileyebilmesi hem liderlik rollerini kazanan öğretmenler açısından, bazen de tehdit edildiği hissine kapılan okul yönetimi ile üretken ilişkileri geliştirme açısından bu etkenlerin önemi açıktır. Ayrıca öğretmen grupları arasında liderlik rolünü kazananlar ve kazanamayanlar gibi yabancılaşmaya yol açabilen anlaşmazlıklar da olabilir (Katzenmeyer ve Moller, 2001; Clemson-Ingram ve Fessler, 1997; Lieberman, 1988'e atfen Harris, 2005: 211). Bu tür anlaşmazlık ve zorlukların üstesinden gelebilmek öğretmen liderin kişiler arası becerilerini ve öğretmenleri değişim ve liderliğe teşvik eden bir okul kültürünü gerektirmektedir.

\section{Öğretmen Liderliği}

Günümüzde liderliğin çeşitli türleri olması sebebiyle pek çok liderlik tanımı da mevcuttur. Eğitimde liderlik neler getirir, eğitim ve liderlik eğitimi arasındaki ilişki nasıldır? Bir anlamda eğitim sürecinde bulunmanın, liderlik öğrenimi olduğu ifade edilebilir. "Eğitim" kelime olarak Latince'de rehberlik etmek anlamındaki "educare" kelimesinden gelir. Eğitimcilerin liderlik davranışlarını göstermeleri beklenir. Ancak bu liderliğin hangi modellere dayandırılması gerektiği de önemlidir. Diğer pek çok süreçte olduğu gibi, eğitimde de yeni yapılanmalara ve yeni liderlik modellerine ihtiyaç duyulmaktadır. Çağdaş liderlerin işi, yeni liderlik modelleri arasından yeni örgütsel modeller yaratmaya yardımcı olmaktır (Urbanski ve Nickolaou, 2006). 
Öğretmenlerin liderlik düşünceleri, bütün öğrenciler için öğrenme ve öğretmenin kalitesini artırma isteklerine dayanır. Araştırmalara göre öğretmenler, liderliğin örgütsel hiyerarşide "daha yüksek" ve "daha üstün" pozisyon olarak tanımlanmasından çok liderliği, işbirlikçi çaba, mesleksel gelişimi ve büyümeyi desteklemek için diğer öğretmenlerle "bütünleşme" ve eğitim hizmetlerinin gelişmesi olarak görüyorlar (Devaney, 1987; Troen ve Boles, 1992'e atfen Dimock ve Mc Gree, 1995).

"Öğretmen liderliğì" terimi, üst üste çakışan ve rekabetçi tanımların var olduğu uluslararası literatürden anlaşılmaktadır. Literatürdeki son incelemeler (Muijs ve Harris, 2003; York-Barr ve Duke, 2004), öğretmenliğin farklı etkilerine işaret etmekte, hatta çatışan ve rekabet içerindeki bir çok tanımına yer vermektedir. Örneğin liderliğin yöneticilik ve denetçilik gibi çeşitli anlamları da vardır (Sacken, 1994). Tam bir tanımının verilememesi, öğretmen liderliğini geniş aktivite, rol ve davranış alanları açısından kaçınılmaz şekilde etkilemiştir. Sonuçta öğretmen liderliği için, sık sık farklı yerlerde farklı anlamlara gelen "şemsiye ibaresi”" kullanılmıştır. Öğretmenliğin okulun tüm etkinliklerini kuşatan işlevlerine yer verilmiştir. Her okulda lider olan ya da liderlik potansiyeli olan öğretmenler vardır. Eğer öğretmenlerin liderliklerinden okulun ve öğrencilerin nasıl faydalanacağı açıç̧a ortaya konulur ve desteklenirse bu kaynaktan yeterince yararlanılabilir. Politika yapanlar, yöneticiler ve sınıf dışındaki diğer liderler, öğretmen liderlerle gerçekçi diyaloglar oluşturmak ve başarmak için ihtiyaçları olan kaynakları bulma sorumluluğuna sahiptirler (Moller, 1999).

\section{Liderlik ve okul kültürü etkeni}

Gerçek yaşamda, örneğin Amerika'daki okullarda öğretmen liderliği bir norm olmadığı gibi, öğretmenlerin pek çoğu kendisini liderlik rollerinden uzak hissederler. Eğitim sistemi doğrultusunda verilen mesaj, "liderliğin başkasının işi olduğu" yönündedir. "Öğretmenler öğretir; okul müdürleri yönetir." Bu gerçeği değiştirmek adına okul kültüründe değişiklikler gerekecektir (Urbanski ve Nickolaou, 2006). Yöneticilerin öğretmenler ve diğer çalışanlarla birlikte oluşturdukları örgüt kültürü, öğretmen liderliğini 
destekleyecek ve sonuçta okulda ve sınıfta öğretmen liderliği davranışları daha fazla gösterilebilecektir (Can, 2006).

Liderliği ve başarıyı destekleyen okul kültürünü oluşturmak bilinçli çabalar gerektirdiği gibi kendi içerisinde de riskler taşıyan bir süreçtir. Öğretmen liderliğinin “kültür oluşumu”'okul müdürlerine olduğu gibi öğretmenlere de korkutucu görünebilir. Her şeyden önce, hem okul müdürleri, hem de öğretmenler aynı yapılanmanın öğeleri ve sonuçlarıdırlar. Bu olgunun gereği olarak öğretmenler ve okul müdürleri, kamu eğitiminin sadece hiyerarşik ve makama dayalı liderliğe ihtiyaç duyduğu iddiasından kurtulmalıdır. "Biz ve onlar” ifadesi, öğretmenlerin okul yöneticilerinin karşıtı bulunması anlamında olmayıp, sistemi ve her iki tarafın da potansiyelini bastıran veya engelleyen yapıların karşısında öğretmen ve yöneticilerin bulunması anlamında anlaşılmalıdır. Öğretmenler ve yöneticiler, bu sorumluluğu taşımalarının yanı sıra, öğrenci başarısı adına bu tür yüklenmelerin gereklerini de yerine getirmelidirler (Urbanski ve Nickolaou, 2006). Öğrenimi ve öğretimi destekleyen örgüt kültürü doğal olarak öğrenci başarısına odaklanacaktır. Belirtilen nedenlerle okul kültürünün okulda işbirlikçi kültürlerin oluşumunu teşvik etmesi ve okullardaki genel öğrenimi geliştirmesi gerektiği ileri sürülmüştür (Caine ve Caine, 2000'atfen Harris, 2005).

Öğretmenin okulda ve eğitim sürecinde uygun liderlik görevini üstlenmemesinin birçok nedeni bulunmaktadır. Bunların başında uygun olmayan yönetimsel yapı ve özendirici olmayan ve desteklemeyen güven ortamı vardır. Yönetimsel otoritenin yasalarına uygun olarak kurulmuş ve sorgulanmamış bir sistem öğretmenlere miras kalmıştır (Sacken, 1994). Bu mirasta, evde oturup çocuklarını yetiştiren "iyi”" bir annede olduğu gibi, "iyi" bir öğretmenin de sınıfta bulunup öğrencilerini yetiştirmesi beklenirdi. Bu yüzden liderliği amaç edinen bir öğretmen "çocuklarını terk etmek" suçlamasıyla karşı karşıya kalırdı. Ayrıca tam gün sınıfta bulunmak, iletişim, etki ve liderlik konularında öğretmenin zamanını ve enerjisini kısıtlıyordu. Kültür ve geleneklerin kaybolması, öğretmenlerin temel görevinin öğreticilik olduğunun ve sınıfların sadece yasal olarak nüfuzları altında bulunduğunun düşünülmesine yol aç1yordu (Urbanski ve Nickolaou, 2006). Bu tür düşünce, değer ve davranışlar öğretmen liderliğinin engellerini oluşturmakta, doğal olarak 
bunların gözardı edilmesi okul çaplı etkinlikleri zayıflatmaktadır. Bu nedenlerle temelinde kültürel öğeler bulunan öğretmen liderliğinin ve liderlik davranışlarını göstermenin engellerinin bilinmesi önem taşımaktadır.

\section{Liderlik Engelleriyle Karşılaşmanın Kaçınılmazlığı}

Liderlik rolleri önemli yararlar sağlamakla birlikte, bu yararların ortaya konulmasının pek çok engel ve güçlüğü yenmeye bağlı olduğu da görülmektedir. Araştırmacılar, lider öğretmenlerin yeni rolleri ve ilişkilerini tartışırken pek çok sınırlamalarla da karşılaştıklarını belirtmişlerdir (Dimock ve Mc Gree, 1995). Bunlar arasında okul kültürü, rol tanımları ve zaman gibi sinırlamalar sayılabilir.

\section{a. Okul Kültürü}

Okulun yönetim ortamı ve desteği öğretmen liderliğinin temel etkenlerindendir. Okul yöneticilerinden ve meslektaşlarından destek ve teşvik görememe lider öğretmenler için en büyük engeli oluşturuyor. Lider öğretmenler, okulun gizil ve tecrit normlarının, birlikteliği sürdürmeyi ve görüşleri paylaşmayı zorlaştırdığını düşünüyorlar. Lider öğretmenler, liderlik rollerini desteklemede başarısız oldukları ve düşmanca bir ortam oluşturdukları için yöneticileri suçluyorlar (Hart, 1990; Troen ve Boles, 1992'ye atfen Dimock ve Mc Gree, 1995). Wasley (1991) de, öğretmenlerin eğer elde etmek istiyorlarsa rollerinin ne olduğuna karar vermeleri, karar alma toplantılarına katılmaları ve okul yönetimi tarafından desteklendiklerini hissetmeleri gerektiğini ifade etmektedir (Harris, 2005:211). Liderlik davranışlarının gösterilmesinin temel etkenlerinden birinin, işbirliğini destekleyen okul kültürü olduğu bilinmektedir. Diğer bulgular da, öğretmen liderliğinin yalnızca en işbirlikçi ortamları geliştirmesini değil, ayrıca öğretmen liderliği görevlerinden biri olan okulda işbirlikçi kültürlerin oluşumunu teşvik etmesi ve okullardaki genel öğrenimi geliştirmesi gerektiğini de ortaya koymaktadır (Caine ve Caine, 2000; Little, 2000'e atfen Harris, 2005:211). Güçlü okul kültürünün oluşturulmasında, becerileri olan girişken öğretmenler, işbirliğine ve desteklemeye yatkın meslektaşlar, yeterli zaman, demokratik katılım ortamı gibi etkenler yanında destek ve teşvik ortamını hazırlayan yönetici etkeni de 
bulunmaktadır. Bunun olmaması, liderlik davranışını gösterebilmenin temel engellerinden birinin bulunduğunu göstermektedir.

\section{b. Rol Tanımları}

Sorumluluklar liderlikle ilişkili olduğundan iyi betimlenemiyorsa, sadece lider öğretmenlerde değil onlarla çalışan diğer insanlarda da (örneğin, yöneticiler, sınıf öğretmenleri) gerginlikler artar, karışıklıklar ortaya çıkar. Yine de araştırmacılar, lider öğretmenlerin yeni rollerini yaratma ve tanımlama gerekliliğine işaret ediyorlar. Öğretmen liderliği ile ilgili araştırma bulgularının çoğu, paylaşılmış normlar ve değerlerin önemine ve öğretmenler arasında örgütlenmeye yönelik işbirlikçi uygulamalara işaret etmektedir (Caine ve Caine, 2000; Little, 2000'e atfen Harris, 2005:211). Öğretmenlerin yeni etkinlik ve projeler yürütülürken daha az engelle karşılaşmaları açısından, kavram kargaşaları yaşamamaları, iletişim ve işbirliğinde farklı algılamalarla karşılaşmamaları için liderlik eylemleriyle ilgili kavramların, rollerin ve görevlerin yeterince anlaşılır ve paylaşılır nitelikte olmasına dikkat edilmelidir.

\section{c. Zaman}

Lider öğretmenler, zaman kısıtlamasının hem liderlik hem de öğretmenlik rollerinde başarılı olma becerilerini önemli ölçüde sınırlandırdığını belirtiyorlar. İlave sorumluluklar yüklendiklerinde veya çok az ilave zamanla öğretmenler her iki rollerinde de etkili olma yeteneklerinden ödün vermeye zorlaniyorlar (Dierks, vd, 1988, Fay ,1992, Lieberman, vd., 1988; Porter, 1986; Wasley, 1989' a atfen Dimock ve Mc Gree, 1995). Oysa öğretmenlerin etkililik düzeylerinin yükseltilmesi için gerçekleştirecekleri kadar sorumluluklar yüklenmeleri gerekir. Aksi durumda ilave alınan sorumluluklar, yetersiz ölçülerde yerine getirilecek, zaman baskısı işlerin kalitesini düşürdüğü gibi öğretmen ve çevresindekileri de huzursuz bir atmosfere sokacaktır.

\section{Öğretmen Liderliğinin Güçlükleri}

Öğretmen liderliğinin davranış olarak gösterilmesini zorlaştıran birçok güçlügün olduğuna ilgili alanyazında yer verilmiştir (Katzenmeyer ve Moller, 2001). On yedi öğretmen liderle yaptıkları çalışmada Lieberman ve diğerleri 
(2000)'ne göre, meslektaşların eşit statüde olmaları, mesleksel etiğin bazı öğretmenler tarafından yanlış anlaşılması ve liderlik rolü biçilen öğretmenlerin sık sık kendilerini meslektaşlarından izole edilmiş bir şekilde bırakıldıklarını algılamaları, liderlik davranışını gösterebilmenin temel güçlüklerini oluşturur. Troen ve Boles (1992)'1n üzerinde çalıştıkları bayan öğretmenler, öğretmen liderliği etkinliklerini gösterdikleri zaman meslektaşları ile bir ilişki kopukluğu yaşadıklarını belirtmişlerdir. Little (2000) da altı okulda 282 öğretmen arasında meslektaşların liderliği kabul etme düzeylerini incelemiş ve liderliğin kabulü konusunda yaşanan sorunları saptamıştır (Harris, 2005:211).

Bugün, liderlik rolleri öğretmenlere eğitimsel değişimleri etkilemek için-sınıfı terk etmeden-gerçek fırsatlar ortaya çıkarıyor ve yeni kazanımlara fırsat hazırlıyor. Öğretmenler liderlik rollerini oynayarak, araştırmacı meslektaşlar olarak hizmet ediyor, yeni öğretmenlere danışman olarak rehberlik hizmetleri veriyor ve uzman öğretmen olarak mesleksel gelişim etkinliklerini kolaylaştırıyorlar (Dimock ve Mc Gree, 1995). Öğretmenler olumlu değişimle sonuçlanacağına bizzat inandıkları programlan kendi kararlarıyla geliştirerek ve uygulayarak bir dizi yeni ve benzersiz liderlik rollerini de sergiliyorlar (Troen ve Boles, 1992).

Mevcut eğitim sistemlerinin bir kısmı, öğretmenlerin liderlik özelliklerinin gelişmesine engel olarak değerlendirilmektedir. Program hedeflerine mutlaka ulaşılması beklentisi, liderlik davranışı gösteremeyen yönetici tutumları, öğretmenler arası iletişimsizlik, bürokratik süreçler bu engellerden bazlarıdır. Gereksinimlere göre geliştirilmeyen programlar iletişimi kısıtlamış, yeni bilgilerden yoksun kalma korkusu ise, öğretmenleri öğretmen olmayan “uzmanlar”a -en iyi olasılıkla önceki öğretmenlere- bağlı kılmıştır (Urbanski ve Nickolaou, 2006). Öteden beri öğretmenler, tepkisizlikleri, girişim ve işbirliğinden uzak olmaları sebepleriyle bu türlü yetersizliklerinden dolayı suçlanmışlardır. Pek çoğunun, "öğretmeyi sevdiği ancak işinden nefret ettiği" konusunda seslerini yükselttikleri bile görülmüştür (Urbanski ve Nickolaou, 2006).

Okullardaki bu türlü hiç de demokratik olmayan yanlış süreçler zararlı sonuçlar ortaya çıkarmıştır. Olumsuz göstergeler bağlamında bazı kişiler, yaratıcılığı engelleyen koşullar karşısında becerilerini kullanamaz 
görünmüşlerdir. Deborah Meier'in de "farklı şekilde itaat" olarak adlandırdığı gibi onlar, öğrencileri karşısında ahlak ve vicdanlarına göre hareket ettiler. Kimi öğretmenler izinsiz olarak bazı yenilikler yanında denetmenleri mutlu etmek üzere de ders planları yaptılar. Ancak-resmi denetim dönemi dışında-bu planlar sınıfta gerçek anlamda işlenen dersleri yansıtmamış, diğer bir söyleyişle, kimileri teoride ve pratikte farklı ikili süreçler takip etmişlerdir. Bu ikilik sonuçta öğretmenliğin bir parçası haline gelmiştir. Ayrıca sınıftaki otonomi adına öğretmenler, okuldaki etkililiklerini gözden çıkarmışlardır (Urbanski ve Nickolaou, 2006). Öğretmenlerden beklenen, sınıfı ve okulu ihmal etmeden, okul çaplı projeleri yürütürken açık bir sınıf yönetimi politikalarıyla öğretmen liderliği rollerini gösterebilmektir.

Birçok araştırma lider öğretmenlerin genel olarak yeni rollerini ve sorumluluklarını büyük ölçüde yeterli bulurken ayrıca çeşitli sınırlama ve gerilimlerle de karşılaşıldığını göstermektedir (Dimock ve Mc Gree, 1995). Öğretmen liderliğinin çeşitli sınırlamaları ve engelleri olmakta, bu engeller de çeşitli etkenlerle ilişkilendirilebilmektedir. Bu bağlamda bir okul içerisinde öğretmen liderliğinin başarısı veya başarısızlığı, diğer öğretmenler ve okul yönetimi ile ilişkiler gibi kişiler arası birçok faktörden etkilenebilmektedir (Katzenmeyer ve Moller, 2001'e atfen Harris, 2005).

Öğretmen liderliğini uygulamaya yansıtmayı daha fazla zorlaştıran birçok engelin olduğu alanyazında farklı başlıklar altında incelenmektedir (Katzenmeyer ve Moller, 2001). Zamanın baskısı, meslektaşları ile yeni ilişki kurmanın stresi, diğer insanların yeni görüşlere karşı direnci, öğretmen liderlerin karşılaştığı sorunların sadece bir kaçı. Destek olunmazsa, öğretmen liderler bu engellere yeniliyorlar ve kendi sınıflarının dışlanmasına destek oluyorlar. Aşağıda bu engellere yer verilmiştir (Moller, 1999).

\section{Öğretmen Liderliğinin Diğer Engelleri}

Farklı kaynaklarda öğretmen liderliğinin engelleri farklı başlıklar altında incelenmekle beraber kapsayıcılığı dikkate alınarak Moller (1999)'in sıralaması esas alınarak aşağıdaki engellere yer verilmiştir. 
Zaman: Yukarıda da değinildiği gibi öğretmen liderliği davranışlarını göstermenin temel engellerinden biri zamandır. Bir günde sadece 24 saat var. Aile, sınıf, okul gibi tüm önemli alanlara yeterince yoğunlaşmanın en büyük engelini zaman oluşturuyor. Sınıf dışı anlarda yapılacak etkinlik ve rollerin ortaya konulması, günlük gereksinimlerin karşılanması ve beklenmeyen durumlarla başedilebilmesi için zamanı etkili bir şekilde programlamak çok önemli. Bu, yapılması çok kolay olmayan ancak yapılabilir bir eylemdir. Her şeyden önce yapılabilir bir işi yapmaya istekli olmak ve bunu da eyleme dönüştürmek gerekir.

Şüphecilik: Kimi öğretmenler, kendilerinden birinin (lider öğretmenin), olduğu konumdan yukarı çıktığını düşünüyorlar. Hareket edenleri ve girişimcileri dışlıyorlar. $\mathrm{Bu}$ belki eğitimcilere saygı duyulmaması yüzündendir. $\mathrm{Bu}$ tür durumlarda genellikle kişilik çatışmaları ortaya çıkmaktadır. Öğretmenlerin bir kısmı, kendi yapmadıkları veya yapamadıklarını meslektaşlarında gördüklerinde onu takdir etmek yerine endişelerini ve şüphelerini ortaya koyuyorlar. Bu tür şüphecilik davranışları da girişken öğretmenlerin cesaretini kırıyor.

Direnç: Karşılaşılan engellerden birisi, yeni yaklaşımları denemekte olan kıdemli öğretmenlerin isteksizlikleridir. Hep aynı eski eylemleri yapmaya devam edenler hep aynı eski sonuçları alırlar. Liderlik daha orijinal hedeflere ulaşmak üzere yeni çabaları ortaya koyabilmektir. Alışılan eylemleri kanıksayan öğretmenler görmedikleri bir eylemi kabullenmekte zorlanırlar ve buna direnç gösterirler.

İlk yıllar: Öğretmen olarak çalışılan kurumda personel geliştirme açısından en önemli etken öğretmen liderliğidir. Personel geliştirme çabalarının ilk yılında olmak, öğretmenliğin ilk yılında olmak gibidir. Geliştirme çabaları hem bu tür programları ortaya koyanlar hem de bu programlardan geçecek öğretmenler açısından zor bir süreçtir. Bu nedenlerle ilk girişimlerin ve ilk yılların öğretmen liderliğinin engellerinden biri olabileceğini gözden kaçırmamak gerekir.

Çoklu roller: Gün içinde farklı rollere girmek, yeni geçişler yapmak bazen zorlayıcı olabilmektedir. Öğretmek, ailelerle iletişim kurmak, öğretmenler arası 
iletişim ağı oluşturmak ve öğrencilerle çalışmak, üstelik tüm bu rolleri aynı zamanda yapmak zorunda olmak kolay işler değil. Liderlerin aynı gün içerisinde farklı görev ve rolleri sergilemek zorunda bulunmaları önemli bir engeli oluşturur. Kimi zaman lider öğretmenlerin birbirine karıştırmadan çoklu rolleri oynamaları da gerekir. Çevredeki diğer insanlara ya da meslektaşlara düşen görev, liderin görev ve rollerini paylaşarak ona destek olabilmektir.

Destek durumu: Müdürün kişisel yetenekleri, öğretmen liderlerin, liderlik rollerini üstlenmelerinde önemli bir desteği oluşturur. Dinleyen, öğretmenlere cesaret veren ve öğretmen liderlere destek olan bir yönetici, okul içinde çok zor olan yenilik yapma görevinin üstlenilmesini teşvik etmektedir. Araştırmalar, okullarda özerklik elde eden ve liderlik rollerini kazanan öğretmenlere karşı öğretmen liderliğinin gelişimine büyük bir engel olan okullardaki "en üst-en aşağı" yönetim yapılarına işaret etmektedir. İş örgütlerini inceleyen Wheatley (2000), örgütlerdeki bürokratik ve hiyerarşik yapıları sürdürmede temel bir yapılanma olarak, korku ve şüpheyi öne çıkaran kontrol süreçleri aşırı bir şiddete işaret etmektedir. Bunun doğal sonucu, öğretmen liderliği rollerinin yönetim tarafından başarılı bir şekilde empoze edilememesidir (Harris, 2005:211). Yönetim desteği yanında öğretmen liderler, çalı̧̧malarını anlayan diğer öğretmenlerin dostluklarını da arıyorlar. Çevresinde izleyici ve istekli meslektaşlarını gören öğretmenler liderlik davranışlarını uzun süreli gösterebilme şansını kazanmış olurlar.

\section{Problem}

Öğretmen liderliği üzerine araştırmalar yapılmakla beraber öğretmen liderliğinin engelleriyle ilgili bağımsız çalışmalar sınırlı düzeydedir. Öğretmen eğitiminin geniş kapsamlı bir alan olmasına karşılık öğretmenlikte liderlik becerilerini geliştirmek için hazırlanan programların hedeflenen düzeyde yararlı olup olmadığı konusunda da yeterli bulgular yoktur. Bu bakımdan bu konularda araştırmalar yapılması ve katılımcıların da yorumlarının alınarak sonuçların ortaya konulması gerekir (Gehrke, 1991). Lider öğretmenlerin işi öğretmen beklentilerini, öğretmen bilgi temelini ve öğretmen uygulamalarını etkilemektir. Öğretmen sorumluluğu ve kalitesinden söz edilirken, artık kent ve kırsal bölge 
okullarındaki öğrencilerin yarısının liseye hiç gitmedikleri gerçeği görmezlikten gelinememektedir. Bu bağlamda, acilen öğretmen liderliğinin ve potansiyelinin incelenmesi gerekir (Sledge ve Morehead, 2006; Lord ve Miller, 2000).

$\mathrm{Bu}$ araştırma, öğretmen liderliği kavramlarını açıklamak ve ilköğretim ve orta öğretim okullarındaki öğretmenlerin öğretmen liderliği davranışlarını göstermelerinin engellerini saptamak amacıyla yapılmıştır. Öğretmen liderliği kavramları literatüre dayalı olarak açıklandıktan sonra araştırmada, görüşme yapılırken mülakat soruları olarak da kullanılan alt problemler aşağıya çıkarılmıştır.

1. Öğretmen liderliği nedir?

2. Öğretmenlere ve yöneticilere göre öğretmen liderlerin gösterdikleri davranışlar nelerdir?

3. Öğretmen liderliği davranışlarının engelleri nelerdir?

4. Engeller, ilköğretim ve orta öğretim okullarına göre farklılaşmakta midir?

\section{Metod}

Araştırma problemiyle ilgili veriler alanyazın taraması ve mülakat yolu ile toplanmıştır. Önce yerli ve yabancı kaynaklara ulaşılarak geniş bir alanyazın taranmış, bu yöntemle sağlanan veriler sistematik olarak analiz edilip ortaya konulduktan sonra elde edilen bilgiler sonucunda hazırlanan ve geliştirilen mülakat (görüşme) soruları çalışma evreninden rasgele (random) seçilen çalışma grubuna uygulanmıştır. İlk soruyla ilgili veriler literatür taraması sonuçlarına göre oluşturulmuş, diğer üç soruya alınan yanıtlar analiz edilmiştir. Görüşme soruları 2006 yılında Kayseri Nevşsehir ve Kahramanmaraş illerinde ilköğretim ve orta öğretim okullarında çalışan 180 öğretmen ve 60 okul yöneticisine dağıtıldı. Öncelikle bütün yöneticilere görüşme yapılması önerildi. Görüşmeyi kabul eden 12 yönetici ve 35 öğretmenle kendi okullarında yüzyüze görüşmeler yapıldı. Toplam görüşme formunun \% 80'i olan 190 form geri döndü. Veriler analiz edilip cevaplar tek tek okunarak \%70'nin üzerinde paylaşım gösteren düşünceler bulgulara alındı ve informal fakat kontrollü 
yapılan bu görüşmeler yazıya geçirildi. Görüşmelerde her katılımcıya aynı soru soruldu. Bu çalışma öğretmen ve yöneticilerin kendi görüşlerini, tecrübelerini ve katıldıkları öğretmen liderliği davranışlarını ve engellerini göstermektedir. Kullanılan tekniklerle sağlanan verilere dayalı bulgular aşağıya çıkarılmıştır.

\section{Bulgular ve Tartışma}

$\mathrm{Bu}$ bölümde öğretmen ve yöneticilerin görüşlerine göre öğretmen niteliği ve liderlik davranışları ile öğretmen liderliği davranışlarının engelleri ortaya konulmuş ve tartışılmıştır.

\section{Öğretmen Liderliği Davranışları ve Müdürün Etkileri}

Öğretmen ve yöneticilerin vurguladığı, öğretmen liderlerin gösterdikleri davranış listeleri incelendiğinde önemli benzerlikler ortaya çıkmıştır. Bu benzerlik okul türlerine göre de önemli ölçüde değişmemektedir. Öğretmenlere göre, öğretmen liderlerin özellikleri; mesleği sevmek, öğrenciyi sevmek, özverili çalışmak, öğretim plan ve programlarının gereğini yerine getirmek, sınıfı iyi yönetmek ve okul etkinliklerine yardımcı olmaktır. Okul yöneticilerine göre ise, milli eğitimin genel ve özel amaçlarını gerçekleştirmek, öğretmenlik genel kültür, alan ve meslek bilgilerine sahip olmak, sınıfta disiplini sağlamak, kendini geliştirmek, niteliklerini artırmak, genel kurallara uymak ve okul etkinliklerine yardımcı olmaktır. Sıralanan öğretmenle ilgili beklentiler öğretmenlerin liderlik davranışları olarak da belirtilmektedir. Öğretmen ve yöneticilerin, öğretmen liderliği davranış listeleri karşılaştırıldığında benzerlikler bulunmaktadır. Ancak öğretmenler sınıfla ilgili öğretim etkinliklerini, yöneticiler ise kaliteli eğitimi, disiplini ve okul çaplı etkinlikleri daha çok vurgulamışlardır.

Öğretmenler, öğretmen liderliğinde müdürün kendilerini motive etmesini, desteklemesini çok önemsiyorlar. Onun ortam ve imkan hazırlaması olmadan çalışmalarının sınıf etkinliklerinden ibaret olacağını belirtiyorlar. Bir öğretmen: "okul müdürümün okulda güven havasını oluşturması önemli, onun güler yüzle "merhaba" demesi bile beni etkiliyor. Yaptıklarımı öğen, yapacaklarımı önemseyen bir müdür beni cesaretlendiriyor. Bu tavır hem sınıfta hem de okulda moral ve verimliliğimi etkiliyor" yanıtını vermişstir. $\mathrm{Bu}$ 
öğretmenin ifadelerinin benzerlerini diğer öğretmenler de kullanıyorlar. Katzenmeyer ve Moller (2001), okul müdürünün davranış biçimini öğretmen liderliği davranışının etkilediğini belirtiyor. Barth (2000) da okul müdürünün liderlik davranışını teşvik etmesinin önemini vurgularken bunun aynı zamanda müdürün kendi liderliğini de pekiştirdiğini belirtmektedir.

Öğretmen liderliği davranışlarının gösterilmesinde yöneticilerin etkisini okul müdürleri de önemsiyorlar. Ancak ilk girişimin öğretmenden gelmesi gerektiğini, kendilerinin yapılan ve yapılacak etkinlikleri destekleyeceklerini belirtiyorlar. Bir okul müdürü şu ifadeleri kullandı: "İsteyen öğretmen program dahilinde yapacaklarını sınıfta yapar, sınıfını her yönden diğer sınıfların önüne geçirebilir. Benim görevim, fiziksel ve teknolojik ortamı öğretmenlere sunmak, bazen teknoloji yetersizliği olabilir. Ama bazı öğretmenler yapmadıkları işlerin engelinin müdür olduğunu belirtiyorlar". Benzer cümlelerle yöneticilerin çoğu bu görüşlere katılıyorlar. Öğretmenin bağımsız ya da diğer öğretmenlerle yapacakları etkinlikleri hem öğretmenler hem de müdürler önemsiyorlar. Ancak ayrıntıda ve etkinliğin gerçekleştirilmesi yönteminde farklı değerlendirmeler ortaya çıkmaktadır. Güven veren, özendirici okul ortamı öğretmenlerin liderlik davranışlarını önemli ölçüde etkilemektedir. $\mathrm{Bu}$ ortamın oluşturulması, geliştirilmesi ve desteklenmesinde de okul yöneticisinin etkisi büyüktür. Schlechty (1990:42) müdürlerin, öğretmen liderlerin ortaya çıkmasına yardımcı olan koşulların yaratıcısı" olabileceklerini; demokrasi sınırları içerisinde öğretmenlerin sorumluluklarını uygun şekilde paylaşmaları konusunda onlara destek verebileceklerini (Urbanski ve Nickolaou, 2006) belirtmektedir. Ancak bu görüşe herkes katılmamaktadır. Clark (1988:3) bir kısım öğretmenin "yaratıcılıktan uzak, her şeyi başkalarından bekleyen, tembel ve sorumsuz ayrıca kontrol edilmeyi, yönlendirilmeyi tercih eden kişiler" olduğunu ifade ederken Sacken (1994) ise değişik bir bakış açısıyla yaklaşmakta ve yöneticinin yapacağı işlerin öğretmenler tarafından yönlendirilmesi gerektiğine vurgu yapmaktadıdr. 


\section{Öğretmen Liderliği Davranışlarının Engelleri}

Öğretmen liderliği davranışlarıyla ilgili sıralanan olası engellere öğretmen ve yöneticilerin katılım yoğunlukları dikkate alınarak yapılan sıralama aşağıya çıkarılmıştır. Öğretmen liderliği davranışlarının engelleri:

- Okul kültürüyle ilgili engeller

- Mesleksel yetişme sürecindeki yetersizlik,

- Lider yerine yönetici müdürler,

- Yönetim desteğinin yetersizliği,

- Zaman sinirlılı̆̆

- Öğretmenin formal yükü,

- Diğer öğretmenlerin yetersiz desteği,

- Yetişme ve gelişme ortamının yetersizliği,

- Etkinlik ve kazanımların tam değerlendirilmemesi,

- Meslek sevgisi ve heyecanında azalma,

- Sınav odaklı eğitim sistemi,

- Demokratik güven ve katılım ortamı,

- Kalabalık siniflar,

- İkili öğretim,

- Bürokratik engeller,

- Ücret yetersizliği,

- Eğitim teknolojisindeki yetersizlik,

- Fiziksel ortam ve olanaklar.

Okuldaki ilişkiler, işbirliği, sosyo-kültürel, sanatsal, bilimsel etkinlikler benimsenmiş ve süreklilik özellikleri ve değeri kazanmış ise öğretmenler daha özgür, girişken ve cesaretli davranışlar gösteriyorlar. Bu tür okul kültürü ortamı, liderlik davranışlarına ve etkinliklerine süreklilik özelliği kazandırıyor. Urbanski ve Nickolaou (2006) okul kültürü ve liderlik davranışlarını gösterebilme değişkenleri arasında ilişkiler kuruyor ve okul kültürünün işbirlikçi kültürü ve liderliği desteklemesi durumunda öğretimin kalitesinin de etkileneceğini belirtiyor (Harris, 1995). Lider özellikleri gösteren yöneticiler, davranışlarıyla model oluyorlar ve öğretmenleri cesaretlendiriyorlar. 
Aksi durum öğretmen liderliği davranışlarının engellerini oluşturuyor. Aynı şekilde öğretmenlerin mesleğe hazırlık sürecinde, güçlü okul kültürü oluşturma ve liderlik eğitiminden geçmemeleri bu tür becerileri öğretmenlik yaşamında da sürdürememelerinin engelini oluşturuyor.

Öğretmenlerin formal ders programları tüm zamanlarını doldurmakta, bu da zaman engelini ortaya çıkarmaktadır. Lider öğretmenler, zaman kısıtlamasının hem liderlik hem de öğretmenlik rollerinde başarılı olma becerilerini önemli ölçüde sınırlandırdığını bildiriyorlar (Dimock ve McGree, 1995). Diğer öğretmenlerin destek olmaması, kıskançlık vs. engelleri de eklenince yeni etkinlik ve projelerin sergilenmesi güçleşmektedir (Moller, 1999). Lisans üstü eğitim ve bilimsel derslere ve kurslara katılım olanaklarının sınırlılığı yanında kazanılan belgelerin özlük haklarında yeterince değerlendirilmemesi ve bazı yöneticilerin ortaya çıkan yetişme fırsatlarını yakalayanlara destek olmaması da yetişme ve gelişme ortamının yetersizliği engelini ortaya çıkarmaktadır. Başka araştırmalarda (Hart, 1990; Troen ve Boles, 1992) da lider öğretmenler, başarısız oldukları liderlik davranışlarının nedenleri arasında yönetici tutumlarını belirmektedirler.

Öğretmenlere göre kalabalık sinıflar öğretmenlerin etkinlik yapmalarını zorlaştırmakta, yöneticiler bu yönüyle de öğretmenlerden ayrılmaktadır. Yöneticilerin üçte biri kalabalık sınıfların daha çok etkinlik için bir imkan olduğunu düşünmektedir. Gerçekte etkinlik yapmak isteyen öğretmen için kalabalık sınıflar çoğu zaman bir engel olarak ortaya çıkabilmektedir. Beklentinin tersine sınav odaklı eğitim öğretim öğretmenlerin liderlik davranışlarını az etkilemektedir. Öğretmenlerin ve yöneticilerin üçte biri öğrenciler açısından yaşamsal önemi olan bir üst okula giriş sınavlarına hazırlık sürecinde öğrencilerin etkinliklere katılmakta isteksizliğini belirtmişlerdir.

Öğretmen liderliği davranışlarının engelleri aslında birbirleriyle ilişkilidir. Kendini geliştirme sürecine giremeyen öğretmen çabuk eskimekte, yaş ilerledikçe meslek heyecanı azalmakta bu da onun rutin eğitim öğretim etkinliklerini tercih etmesine neden olmaktadır. 


\section{Okul kademelerine göre öğretmen liderliği engelleri}

Burada, okul kademelerine göre farklılaşan engellere ve yorumlarına yer verilmiştir. Orta öğretim okullarında ikili öğretim ve ücret yetersizliği engellerine katılım ilköğretime göre daha yüksek düzeyde çıkmıştır. Bunun ilköğretimde normal eğitimin her geçen gün yaygınlaşmasından kaynaklandığı söylenebilir. Lise öğretmeni, hem kendisi hem de öğrencilerin yarım gün okulda bulunmasını farklı etkinlik ve projeler ortaya koyamamasının engeli olarak görüyor. Moller (1999), zaman baskısının öğretmenlerin girişkenlik düzeylerini etkilediğini vurgularken, Dimock ve McGree (1995) de zaman sınılılı̆̆ını, liderlik davranışlarının engelleri arasında sıralıyor. İlköğretim öğretmenlerinin çok azı öğretmen liderliğinde ücret yetersizliğini belirtirken, lise öğretmenlerinin yarısı ücret yetersizliğini ileri sürerek serbest zamanlarda özel iş yerlerinde (dersane gibi) çalışma eğilimini göstermektedir. Bu eğilimin, lise öğretmenlerinin dışarıda çalışma şanslarının daha yüksek olmasından kaynaklandığı söylenebilir.

Okullardaki demokratik olmayan süreçler öğrencilerle beraber eğitim çalışanlarının da cesaret ve yaratıcılıklarını olumsuz olarak etkilemektedir (Urbanski ve Nickolaou, 2006; Can, 2005). Araştırmada ilköğretim okullarındaki öğretmenler demokratik katılım ortamının yetersizliği engeline lise öğretmenlerine göre daha çok katılıyorlar. Aynı şekilde ilköğretimde görev yapanlar bürokratik yapı ve eğitim teknolojilerinin yetersizliği engellerinin varlığını daha fazla paylaşıyorlar. Bu bulgu, orta öğretim okul ortam ve yönetiminin katılım fırsatlarını daha çok sunduğu ve ekstra projeler ve etkinliklerle ilgili yazışma ve izin alma süreçlerinde daha fazla kolaylıklar sağladıkları şeklinde yorumlanabilir. İlaveten orta öğretim okullarının bilgisayar, internet, eğitim araçları gibi olanaklara daha çok sahip oldukları da bu verilerden anlaşılmaktadır. Bu tür teknolojik imkanların öğretmenleri yeni etkinlik ve projelere katılmaya özendirdiği görülmektedir. Yöneticiler ilköğretim ve orta öğretim öğretmenlerinin daha çok katıldıkları bu tür engellere daha az katılıyorlar. Aynı şekilde hem ilköğretim ve hem de orta öğretim okulu yöneticileri yönetim desteğinin yetersizliği engeline öğretmenler kadar katılmıyorlar. Öğretmenlerin istedikleri etkinlik ve projelerini gerek sınıfta 
gerekse okulda yapabileceklerini, kendilerinin bir engel oluşturmadıklarını belirtiyorlar. Başka araştırmalarda (Fay, 1992; Sledge ve Morehead, 2006) da öğretmen ve yönetici görüşleri farklılaşmakta, yönetim desteğinin yetersizliğinin öğretmen davranışlarını önemli ölçüde etkilediği öğretmenler tarafından vurgulanmaktadır.

Öğretmen liderliği açısından, öğretmenler fiziksel ortam ve olanaklarla ilgili herhangi bir engelin olmadığını belirtiyorlar. Bu görüş yöneticilerce de paylaşılıyor. Bu bulgu, ilköğretim ve orta öğretim okullarının fiziksel ortam ve olanaklarının her geçen gün iyileştiğini, sürekli daha olanaklı ve teknolojik bir yapılanmaya kavuşmakta olduklarını göstermektedir. İkili görüşmelerde de aynı düşünceler dile getirilmektedir. Bu yönüyle okullarda öğretmen liderliğinin gösterilmesiyle ilgili önemli bir güçlükle karşılaşılmamaktadır.

\section{Sonuçlar}

Öğretmen ve yöneticilere göre, öğretmen liderlerin gösterdikleri davranış listeleri incelendiğinde önemli benzerlikler ortaya çıkmıştır. Ancak öğretmenler öğrenci merkezli ve sınıfla ilgili öğretim etkinliklerini, yöneticiler ise kaliteli eğitimi, disiplini ve okul çaplı etkinlikleri ve bu yöndeki davranışları daha çok belirtmişlerdir. Öğretmenler, öğretmen liderliğinde müdürün kendilerini güdülemesini, destek ortamı sunmasını çok önemsiyorlar. Müdürün ortam ve olanakları yeterince sunmaması durumunda çalışmalarının sınıf içi sınırlarda kalacağını, hatta yöneticinin yeterli desteğinin öğretmenin sınıftaki cesaretini de olumlu yönde etkilediğini belirtmişlerdir.

Öğretmen liderliği davranışlarının gösterilmesinde yöneticilerin etkisini okul müdürleri de paylaşmakta ancak ilk çabayı öğretmenin göstermesi durumunda, kendilerinin öğretmen önerilerini, düşünce ve etkinlik projelerini destekleyeceklerini belirtmişlerdir.

Güven veren, özendirici okul ortamının öğretmenlerin liderlik davranışlarını önemli ölçüde etkilediği, bu ortamın yaratılmasında da yöneticilerinin payının büyük olduğu katılımcıların çoğu tarafında paylaşılmaktadır. Yöneticilerden bu ortamın oluşturulmasında olduğu gibi, 
sürdürülmesi ve geliştirilmesiyle ilgili de katılımcıların beklentileri bulunmaktadır.

Öğretmen liderliği davranışlarının engelleri hem yöneticilere hem de öğretmenlere göre büyük benzerlik göstermektedir. İlk sıralarda paylaşılan engeller: Okul kültürüyle ilgili engeller, mesleksel yetişme sürecindeki yetersizlik, yönetim desteğinin yetersizliği, zaman sınırlılığı, öğretmenin formal yükü, diğer öğretmenlerin yetersiz desteği, yetişme ve gelişme ortamının yetersizliği, etkinlik ve kazanımların tam değerlendirilmemesi, meslek sevgisi ve heyecanında azalma, sınav odaklı eğitim sistemi, demokratik güven ve katılım ortamının yetersizliği. Bunlardan yönetim desteği ve demokratik katılımın yetersizliği ile yapılan etkinlik ve kazanımların yeterince değerlendirilmemesi engellerine öğretmenler daha fazla katılmaktadırlar.

Orta öğretim okullarında ikili öğretim ve ücret yetersizliği engellerine katılım ilköğretime göre daha yüksek düzeyde çıkmıştır. Lise öğretmeni, hem kendisi hem de öğrencilerin yarım gün okulda bulunmasını farklı etkinlik ve projeler ortaya koyamamasının engeli olarak görmektedir. İlköğretim okullarındaki öğretmenler demokratik katılım ortamının yetersizliği engeline lise öğretmenlerine göre daha çok katılıyorlar. Aynı şekilde ilköğretimde görev yapanlar bürokratik yapı ve eğitim teknolojilerinin yetersizliği engellerinin varlığını daha fazla paylaşıyorlar. Orta öğretim okulu ortam ve yönetiminin katılım fırsatlarını daha çok sunduğu ve ekstra projeler ve etkinliklerle ilgili yazışma ve izin alma süreçlerinde daha fazla kolaylıklar sağlandığı görülmektedir. İlaveten orta öğretim okullarının bilgisayar, internet, eğitim araçları gibi olanaklara daha çok sahip oldukları da bu verilerden anlaşılmaktadır. Bu tür teknolojik imkanlar öğretmenleri yeni etkinlik ve projelere katılmaya daha çok özendirmektedir. Yöneticiler ilköğretim ve orta öğretim öğretmenlerinin daha çok katıldıkları bu tür engellere az katılıyorlar. Aynı şekilde hem ilköğretim ve hem de orta öğretim okulu yöneticileri yönetim desteğinin yetersizliği engeline de öğretmenler kadar katılmıyorlar. Bulgulara göre ilköğretim ve orta öğretim okullarının fiziksel ortam ve olanakları her geçen gün iyileşme eğilimi göstermektedir.

Öğretmenlerin liderlik davranışlarını geliştirmek üzere, öncelikle öğretmen yetiştirme programlarının zenginleştirilmesi, okul kültürü 
ortamlarının geliştirilmesi önem taşır. İlaveten liderlik davranışlarının engelleri bağlamında yönetim desteğinin artırılması, normal öğretime geçilerek zaman sınırlılığı engelinin azaltılması, meslektaşlar arası destek bilincinin ve güven ortamının geliştirilmesi gerekir.

\section{Kaynakça}

Barth, R. (2000). “The Teacher Leader” Edutopia-online, www.glef.org, The George Lucas Educationam Foundation (11.01.2005).

Can, N. (2006). “Öğretmenlerin Öğretmen Liderliği Davranışları”. Milli Eğitim Bakanlığı Öğretmen Yetiştirme ve Eğitimi Genel Müdürlüğü ile Çanakkale On Sekiz Mart Üniversitesi'nin işbirliğiyle düzenlenen III. Uluslararası Öğretmen Yetiştirme Sempozyumu, Sunulmuş Bildiri, Çanakkale: 4-5 Mayıs, 2006.

Can, N.. (1995). "Türk Milli Eğitim Sisteminde Demokrazi Eğitimi ve Sorunları", Çağdaş Eğitim, 30(321), 31-36.

Caine, G. ve R. N. Caine (2000). The Learning Community as a Foundation for Developing Teacher Leaders. NASSP Bulletin (May), pp. 6-13.

Carnegie Forum on Education and the Economy (1986). A nation prepared: Teachers for the twenty-first century. New York: Carnegie Forum on Education and the Economy.

Clark, David L. (1988). How The Structure and Operation of Schools Should Change. Memo to Seminar Participants: New Models for The Role and Training of Leadership for Tomorrow's Schools. University of Virginia.

Clemson-Ingram, R. ve R. Fesler (1997). "Innovative Programs for Teacher Leadership”, Action in Teacher Education, 19(3), 95-106.

Çelik, Vehbi (1999). Eğitimsel Liderlik. Ankara: Pegem Yayınları.

Devaney, K. (1987). The lead teacher: Ways to begin. New York: Carnegie Forum on Education and the Economy. 
Dierks, K. vd. (1988). Teacher leadership: Commitment and challenge. Unpublished research report, Puget Sound Educational Consortium. Seattle: University of Washington

Dimock, V. B. ve Kathleen M. McGree (1995). Leading Change From The Classroom: Teachers As Leaders,SDLIssues..aboutChange Volume 4, Number 4, http://www.sedl.org/change/Issues/Issues44.html (30.05.2006).

Fay, C. (1992). Empowerment through leadership: In the teachers' voice. In C. Livingston (Ed.), Teachers as leaders: evolving roles. NEA School Restructuring Series. Washington, D. C.: National Education Association.

Gehrke, Nathalie (1991). "Developing Teachers' Leadership Skills". ERIC Clearinghouse on Teacher Education Washington DC, 1991-04-00.

Harris, Alma (2005). "Teacher Leadership: More Than Just a Feel-Good Factor?", Leadership and Policy in Schools, 4:201-219.

Hart, A. (1990). Impacts of the school social unit on teacher authority during work redesign. American Educational Research Journal, 27 (3), 503532 .

Katzenmeyer, M., ve G. Moller. (2001). Awakening the sleeping giant: Helping teacher develop as leaders ( 2 nd ed.). Thousand Oaks, CA: Corwin Press, Inc.

Lieberman, A. (1988). Expanding the leadership team. Educational Leadership, 45(5), 4-8. 
Lieberman, A., E. Saxl, ve M. Miles (1988). Teacher leadership: Ideology and practice. In A. Lieberman (Ed.), Building a professional culture in schools. New York: Teachers College Press

Lieberman, A. (1992). Teacher leadership: What are we learning? In C. Livingston (Ed.), Teachers as leaders: Evolving roles. NEA School Restructuring Series. Washington, D. C.: National Education Association.

Little, J.W. (2000). Assessing The Prospects for Teacher Leadership. The Jossey-Bass Reader on Educational Leadership, pp. 24-43. Chicago: Jossey-Bass.

Livingston, C. (1992). Teacher leadership for restructured schools. In C. Livingston (Ed.), Teachers as leaders: Evolving roles. NEA School Restructuring Series. Washington, D. C.: National Education Association.

Lord, Brian ve Barbara Miller (2000). An Appealing and Inescapable Force in School Reform? Education Development Center.

http://www.ed.gov/inits/Math/glenn/LordMiller.doc (10.08.2006).

Moller, Gayle (1999). "You have to want to do this job" Journal of Staff Development, Fall 1999 (Vol. 20, No. 4). http://www.nsdc.org/library/publications/jsd/voices204.cfm (21.06.2006).

Muijs, D. ve A. Haris (2003). "Teacher Leadership: Improvement Through Empowerment". Educational Management and Administration, 31(4), 437-449. 
Porter, A. (1986). Teacher collaboration: New partnership to attract old problems. Kappan, 69 (2), 147152.

Sacken, Donald (1994). No More Principals. Phi Delta Kapa.

Schlechty, Phillip C. (1990). Schools for The Twenty First Century. San Francisco: Jossey-Bass Publishers.

Sledge J.R. ve Morehead P. (2006, Feb). "Tolerated Failure or Missed

Opportunities and Potentials for Teacher Leadership in Urban Schools?"

Current Issues in Education, 9(3). Available:

http://cie.ed.asu.edu/volume9/number3.

Troen, V., ve K. Boles (1992, April). Leadership from the classroom: Women teachers as a key to school reform. Paper presented at The Annual Meeting of the American Education Research Association, San Francisco, CA.

Urbanski, Adam ve M.Beth Nickolaou (2006). "Reflections on Teachers as Leaders".http://mw.k12.ny.us/files/filesystem/REFLECTIONS\%200N\%2 0 TEACHERS. (20.05.2006).

Wasley, P. (1989, April). Lead teachers and teachers who lead: reform rhetoric and real practice. Paper presented at The annual Meeting of the American Educational Research Association, San Francisco, CA.

Wheatley, M. (2000). "Good-Bye Command and Control”, In Fullan (Ed.), The Jossey-Bass Reader on Educational Leadership, pp. 102-135. Chicago: Jossey-Bass. 
Can, N./ Sosyal Bilimler Araştırmaları Dergisi. 2, (2006): 137-161

York-Barr, J., ve K. Duke (2004). "What do we know about teacher leadership? Findings from two decades of scholarship. Review of Educational Research.74(3), 255-316.

Yukl, G. (1994). Leadership in Organizations (Third Edition). Englewood Cliffs, NJ: Prentice Hall. 